\title{
Poor weight gain of the low birthweight infant fed nasojejunally
}

\author{
M F WHITFIELD \\ Department of Paediatrics, University of Sheffield and Neonatal Intensive Care Unit, \\ Jessop Hospital for Women, Sheffield
}

SUMMARY Forty-four appropriately grown preterm infants of birthweight $1-1 \cdot 5 \mathrm{~kg}$ were allocated to nasojejunal (NJ) or nasogastric (NG) feeding at birth. Infants in the NJ group were transferred to NG feeding as soon as they weighed $1.5 \mathrm{~kg}$. The mean caloric intake of infants in both groups was the same, but mean incremental weight velocity during $\mathrm{NJ}$ feeding was significantly less than during NG feeding. At expected date of delivery mean body weight and mean occipitofrontal circumference were significantly smaller in the NJ group. During the 3 months after the expected date of delivery, when all infants were being fed orally, the infants in the NJ group had significantly greater mean weight velocity and mean occipitofrontal circumference velocity than infants in the NG group so that by 3 months after the expected date of delivery there was no significant difference in bodyweight or occipitofrontal circumference between the groups. Low birthweight infants fed by the nasojejunal route from birth should be transferred to nasogastric feeding as soon as possible.

The early provision of an adequate caloric intake in a form which can be tolerated without metabolic or other complications is a major goal in the management of the small sick infant. Transpyloric feeding, either nasoduodenal or nasojejunal (NJ), has been claimed to result in better growth owing to the tolerance of more enteral calories than is possible with conventional nasogastric (NG) feeding, ${ }^{1-6}$ and to reduce the incidence of pulmonary aspiration. On the other hand, Roy et al. ${ }^{7}$ found significantly greater fat malabsorption during $\mathrm{NJ}$ feeding of low birthweight infants allocated randomly to NG or NJ regimens and noted a statistically insignificant faster weight gain in the NG group. A more recent study of low birthweight infants did not show any advantage in NJ compared with NG feeding. ${ }^{8}$

This study was undertaken to observe the effect of NJ and NG feeding in the newborn period on growth of low birthweight infants from birth to 6 months after expected date of delivery (EDD).

\section{Patients and methods}

Patient allocation. All infants admitted to the Neonatal Intensive Care Unit, Jessop Hospital for Women, Sheffield, during the 3-year period from 1 January 1977 to 31 December 1979 weighing between 1.0 and $1.5 \mathrm{~kg}$ at birth who were of normal weight for gestational age were eligible for inclusion in the study (72 infants). Excluded were those suffering from lethal malformations (4 infants), those who died before enteral feeding was begun (16 infants), and those who were not under my direct clinical supervision throughout the period of study (8 infants). Allocation to NJ or NG feeding was by the month of birth with one exception, monozygotic twins of 29 weeks' gestation, one of whom was fed by each route.

General management. All infants were nursed in incubators in a thermoneutral environment with no added humidity. At a body weight of about $1.7 \mathrm{~kg}$, when direct observation of respiration was no longer necessary, the infants were nursed clothed, including a hat, in a cot following the recommendations of Hey and O'Connell. ${ }^{9}$ Respiratory distress syndrome and apnoeic attacks of prematurity were treated by continuous positive airways pressure and intermittent positive pressure ventilation as required. Fluid and electrolyte requirements were provided parenterally in $10 \%$ glucose until $150 \mathrm{ml} / \mathrm{kg}$ per $24 \mathrm{~h}$ of feed was tolerated enterally. No parenteral fat or amino-acid was given. All infants were weighed at least twice weekly by the nursing staff and occipitofrontal circumference measured weekly by resident medical staff or by me. 
Feeding. Cow and Gate Premium infant formula $(63 \mathrm{kcal} / 100 \mathrm{ml}$, Cow and Gate Baby Foods, Trowbridge, Wilts) was used for enteral feeding with occasional supplementation with expressed breast milk as available. The target volumes for enteral feeding were $(\mathrm{ml} / \mathrm{kg}$ per $24 \mathrm{~h}): 60$ on day 1,150 on day 3, and 180-200 on days 7-10. A technique similar to that described by Benda ${ }^{10}$ was used for NG feeding employing a 5 FG polyvinyl chloride tube which was changed daily. The feed was delivered as a bolus by gravity at hourly intervals and later 2 - and 3-hourly as tolerated. Infants having apnoeic attacks were fed hourly. The stomach was aspirated 3hourly and the feed volume adjusted if gastric residues were increasing. Between 34 and 36 weeks' gestational age bottle or breast feeds were gradually introduced when the infants showed signs of sucking.

Discharge home took place when the infants sucked full feeds reliably, were gaining weight adequately, and showed temperature stability, generally at about $2.2 \mathrm{~kg}$ body weight. Infants were seen regularly after discharge and specifically at EDD, and at 3 and 6 months after EDD, for growth measurement.

Infants were fed nasojejunally via a commercially available 6 FG side-opening preweighted Silicone rubber tube (Vygon UK Ltd, Cirencester). The tube was inserted slowly relying on peristalsis. An orogastric tube was also inserted and air insufflation used to aid passage of the NJ tube through the pylorus. When the tube tip was confirmed radiologically to be in the jejunum within $2 \mathrm{~cm}$ of the duodenojejunal flexure a continuous infusion of sterile milk was delivered via a syringe pump aiming at the same target volumes as in NG feeding. Every 3 hours the tube was checked visually for dislodgement and the syringe pump refilled. Syringe pumps were deliberately filled with the correct volume of feed for each 3-hour period to minimise the length of time that milk was 'incubated' at room temperature and to ensure that the fat- and calorie-rich portion of the milk ejected last from a horizontal syringe was delivered completely to the infant. $\mathrm{NJ}$ tubes were not changed routinely. The orogastric tube was aspirated 3 hourly and the aspirate replaced via the $\mathrm{NJ}$ tube. Abdominal distension, milk vomits, gastric residues of more than $5 \mathrm{ml}$, or blood in the stools were indications to stop $\mathrm{NJ}$ feeding temporarily. Transfer from continuous $\mathrm{NJ}$ feeding to 3-hourly NG feeding took place when the infant weighed $1.5 \mathrm{~kg}$.

\section{Results}

Clinical details of infants recruited to each feeding group are given in Table 1. Deaths in the $\mathrm{NJ}$ group
Table 1 Clinical characteristics of 44 infants fed by the NJ or $N G$ route

\begin{tabular}{lll}
\hline & $\begin{array}{l}\text { NJ group } \\
(n=28)\end{array}$ & $\begin{array}{l}\text { NG group } \\
(n=16)\end{array}$ \\
\hline Sex (boys : girls) & $12: 16$ & $10: 6$ \\
Mean birthweight (kg) & $1 \cdot 27$ & $1 \cdot 30$ \\
Range & $1 \cdot 04-1 \cdot 49$ & $1 \cdot 06-1 \cdot 46$ \\
Mean gestational age at birth (weeks) & $29 \cdot 4$ & $30 \cdot 0$ \\
$\quad$ Range & $27-32$ & $28-32$ \\
No given ventilatory assistance & 17 & 8 \\
Deaths & 4 & 0 \\
\hline
\end{tabular}

None of the differences between the NJ and NG groups is statistically significant $(P>0 \cdot 1)$.

stool frequency. There was no case of necrotising were due to ventilatory failure ( 3 infants), and to cot death (1 infant). NJ tube dislodgement was a common problem in the NJ group, occurring on 30 occasions in 17 of the 25 surviving infants fed by this route. There was no significant difference between the two feeding groups in the incidence of pulmonary milk aspiration, vomiting, or abdominal distension, or in the volume of gastric aspirate, or

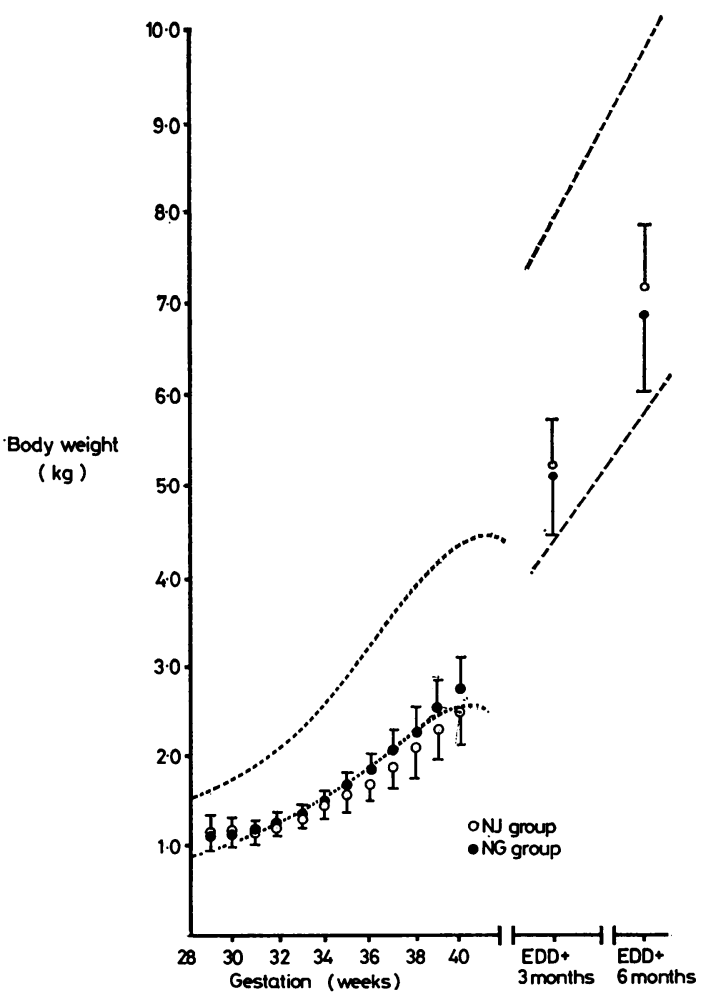

Fig. 1 Mean $( \pm S D)$ body weight of infants in $N J$ and $N G$ groups from birth to EDD 6 months. Interrupted lines give $\pm 2 S D$ s limits for normal growth in utero ${ }^{11}$ and after term birth. ${ }^{12}$ 
Table 2 Growth in bodyweight and occipitofrontal circumference from birth to EDD+6 months in infants fed NJ or $N G$ in the neonatal period

\begin{tabular}{|c|c|c|c|c|c|c|}
\hline & \multirow{2}{*}{$\begin{array}{l}\text { Feeding } \\
\text { group }\end{array}$} & \multicolumn{5}{|c|}{ Corrected age } \\
\hline & & Birth & $\begin{array}{l}34 \text { weeks' } \\
\text { gestation }\end{array}$ & $E D D$ & $\begin{array}{l}E D D+ \\
3 \text { months }\end{array}$ & $\begin{array}{l}E D D+ \\
6 \text { months }\end{array}$ \\
\hline Number & $\begin{array}{l}\mathbf{N J} \\
\mathbf{N G}\end{array}$ & $\begin{array}{l}21^{*} \\
15^{*}\end{array}$ & $\begin{array}{l}21 \\
15\end{array}$ & $\begin{array}{l}21 \\
15\end{array}$ & $\begin{array}{l}18 \\
15\end{array}$ & $\begin{array}{l}16 \\
13\end{array}$ \\
\hline $\begin{array}{l}\text { Body weight (kg) } \\
\text { mean } \pm S D \text { (range) }\end{array}$ & $\begin{array}{l}\text { NJ } \\
\text { NG }\end{array}$ & $\begin{array}{c}1 \cdot 27 \pm 0 \cdot 12 \\
(1 \cdot 04-1 \cdot 49) \\
1 \cdot 30 \pm 0 \cdot 16 \\
(1 \cdot 04-1 \cdot 46)\end{array}$ & $\begin{array}{c}1 \cdot 43 \pm 0 \cdot 15 \\
(1 \cdot 16-1 \cdot 68) \\
1 \cdot 47 \pm 0 \cdot 17 \\
(1 \cdot 14-1 \cdot 75)\end{array}$ & $\begin{array}{l}2 \cdot 50 \pm 0 \cdot 38^{*} \\
(1 \cdot 70-3 \cdot 10) \\
2 \cdot 79 \pm 0 \cdot 39^{*} \\
(2 \cdot 22-3 \cdot 60)\end{array}$ & $\begin{array}{c}5 \cdot 26 \pm 0 \cdot 49 \\
(4 \cdot 50-6 \cdot 00) \\
5 \cdot 12 \pm 0 \cdot 66 \\
(4 \cdot 40-6 \cdot 50)\end{array}$ & $\begin{array}{c}7 \cdot 16 \pm 0 \cdot 74 \\
(6 \cdot 20-9 \cdot 00) \\
6 \cdot 88 \pm 0 \cdot 86 \\
(6 \cdot 30-8 \cdot 00)\end{array}$ \\
\hline $\begin{array}{l}\text { Occipitofrontal circumference }(\mathrm{cm}) \\
\text { Mean } \pm \text { SD (range) }\end{array}$ & $\begin{array}{l}\text { NJ } \\
\text { NG }\end{array}$ & $\begin{array}{c}26 \cdot 8 \pm 1 \cdot 3 \\
(25 \cdot 0-29 \cdot 3) \\
27 \cdot 4 \pm 1 \cdot 1 \\
(26 \cdot 0-29 \cdot 0)\end{array}$ & $\begin{array}{c}29 \cdot 1 \pm 1 \cdot 2 \\
(26 \cdot 8-30 \cdot 1) \\
29 \cdot 7 \pm 1 \cdot 1 \\
(29 \cdot 4-32 \cdot 4)\end{array}$ & $\begin{array}{c}34 \cdot 1 \pm 1 \cdot 2 \dagger \\
(31 \cdot 3-35 \cdot 8) \\
35 \cdot 1 \pm 0 \cdot 9 \dagger \\
(33 \cdot 3-36 \cdot 3)\end{array}$ & $\begin{array}{c}40 \cdot 8 \pm 1 \cdot 2 \\
(38 \cdot 8-42 \cdot 8) \\
40 \cdot 7 \pm 1 \cdot 1 \\
(38 \cdot 0-42 \cdot 5)\end{array}$ & $\begin{array}{c}44 \cdot 3 \pm 1 \cdot 3 \\
(42 \cdot 5-46 \cdot 4) \\
44 \cdot 0 \pm 1 \cdot 3 \\
(41 \cdot 3-46 \cdot 0)\end{array}$ \\
\hline
\end{tabular}

* Infants were included at birth and EDD only if available for study at EDD. 2 and 1 infants were discharged to referral hospitals in NJ and NG groups respectively before EDD so $\mathrm{n}=21$ and 15 respectively. An additional 3 and 5 infants in the NJ group were lost to follow-up at EDD+3 months and EDD +6 months respectively. Two infants were lost to follow-up in the NG group at EDD +6 months.

* Student's $t$ test $\mathbf{P}<0.05$. †Student's $t$ test $\mathbf{P}<0.01$.

enterocolitis or bowel perforation in the study population, but one infant was withdrawn from the study because of intractable abdominal distension after 14 days of $\mathrm{NJ}$ feeding and received total parenteral nutrition.

There was no significant difference in mean enteral feed intake between the two groups at any time between birth and discharge from hospital. Once full feeding was established (about 11 days in each group) the mean enteral calorie intake $( \pm \mathrm{SD})$ remained constant (NJ 121 \pm 11 , NG $122 \pm 10 \mathrm{kcal} / \mathrm{kg}$ per $24 \mathrm{~h}$ ) during the infant's stay in hospital. The duration of $\mathrm{NJ}$ feeding ranged from 5 to 48 (mean 29) days, depending on the time taken to grow from birthweight to $1.5 \mathrm{~kg}$ body weight.

Initial weight loss in the two feeding groups was similar (mean, range; NJ 126, 0-230; NG 123, 40-200 g). During the first weeks of life infants in the NJ group grew more slowly than those fed NG from birth resulting in a significantly lower weight and occipitofrontal circumference at EDD ${ }^{11} 12$ (Fig. 1, Table 2).

Incremental weight velocity (IWV, weight increase (g) per $24 \mathrm{~h}$ divided by the body weight in $\mathrm{kg}$ at the midpoint of the time period during which the calculation was made, $\mathrm{g} / \mathrm{kg}$ per $24 \mathrm{~h}$ ), was calculated in overlapping 2 .week periods for infants in each group. The NG group reached a significantly higher peak mean IWV (Fig. 2 at 5 weeks' postnatal age, NG $17 \cdot 0 \pm 4 \cdot 6(\mathrm{SD}), \mathrm{NJ} 12 \cdot 3 \pm 3 \cdot 6 \mathrm{~g} / \mathrm{kg}$ per $24 \mathrm{~h} ; \mathrm{P}=\mathbf{0 . 0 1 )}$. In order to compare IWV in infants fed exclusively nasojejunally or nasogastrically and to exclude infants fed nasojejunally for only a few

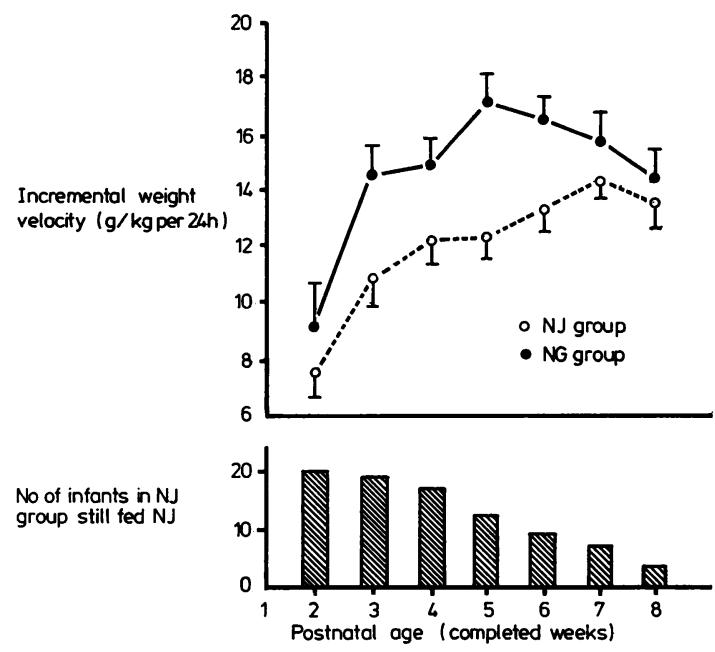

Fig. 2 Mean ( $\pm S E M)$ incremental weight velocity by weeks of postnatal age in infants in $N J(n=22)$ and $N G$ $(n=15)$ groups. Difference at 5 weeks is significant $(P<0.01)$.

Table 3 Incremental weight velocity ( $\mathrm{g} / \mathrm{kg}$ per $24 \mathrm{~h}$ ) from birth to $1.5 \mathrm{~kg}$ body weight in infants fed $\mathrm{NJ}$ or $\mathrm{NG}$ weighing between 1.0 and $1.4 \mathrm{~kg}$ at birth

\begin{tabular}{|c|c|c|c|c|c|c|}
\hline \multirow[t]{2}{*}{ Feeding route } & \multicolumn{2}{|c|}{ Birthweight $(\mathrm{kg})$} & \multicolumn{2}{|c|}{ Gestational age (weeks) } & \multirow{2}{*}{$\begin{array}{l}\text { No of infants requiring } \\
\text { ventilation }\end{array}$} & \multirow{2}{*}{$\begin{array}{l}\text { Incremental weight velocity } \\
(\mathrm{g} / \mathrm{kg} \text { per } 24 h) \text { mean } \pm S D\end{array}$} \\
\hline & Mean & Range & Mean & Range & & \\
\hline $\begin{array}{l}\text { NJ }(n=20) \\
N G(n=10)\end{array}$ & $\begin{array}{l}1 \cdot 25 \\
1 \cdot 23\end{array}$ & $\begin{array}{l}1 \cdot 08-1 \cdot 40 \\
1 \cdot 04-1 \cdot 40\end{array}$ & $\begin{array}{l}29 \cdot 5 \\
29 \cdot 4\end{array}$ & $\begin{array}{l}27-31 \\
28-31\end{array}$ & $\begin{array}{l}7 \\
6\end{array}$ & $\begin{array}{r}7 \cdot 4 \pm 1 \cdot 7^{*} \\
10 \cdot 0 \pm 2 \cdot 0^{*}\end{array}$ \\
\hline
\end{tabular}

* Student's $t$ test $P<0.01$, also significant $(P<0.05)$ for sex compared separately. There is no significant aifference in birthweight, gestational age, or need for ventilation between the two groups.

Mean duration of NJ feeding 33 (13-48) days. 
days, IWV was calculated for infants in both groups of birthweight of $1.4 \mathrm{~kg}$ or less during the period from birth to reaching $1.5 \mathrm{~kg}$ body weight (Table 3 ). Incremental weight velocity was significantly higher in the infants fed nasogastrically.

From EDD to EDD+3 months mean IWV $( \pm$ SD) (NJ $7 \cdot 7 \pm 1 \cdot 6$, NG $6 \cdot 5 \pm 1 \cdot 6 \mathrm{~g} / \mathrm{kg}$ per $24 \mathrm{~h}$, $\mathbf{P}<0.05)$ and mean occipitofrontal circumference velocity $( \pm S D)(\mathrm{NJ} 0.55 \pm 0.08 ; \mathrm{NG} 0.47 \pm 0.06 \mathrm{~cm}$ per week, $\mathrm{P}<0.01)$ were significantly higher in the $\mathrm{NJ}$ group so that by EDD +3 months and EDD +6 months there were no significant differences in body weight or occipitofrontal circumference between the two groups (Table 2, Fig. 1).

\section{Discussion}

Although patient allocation was not formally randomised, allocation of all eligible infants by month of birth recruited two similar groups of infants although there were fewer infants in the NG group (Table 1). Neither type of feeding offered a significant advantage in the incidence of feeding complications and $\mathrm{NJ}$ feeding did not prevent pulmonary milk aspiration. There had been no case of necrotising enterocolitis in our nursery before the study, and the introduction of NJ feeding was not associated with the appearance of this complication. The Silicone rubber transpyloric tubes remained flexible after several weeks in situ.

Claims of superior weight gain with $\mathrm{NJ}$ feeding in the first weeks of life are dependent on increased enteral tolerance of feed by this route. ${ }^{1-6}$ In this study we had little difficulty in passing $\mathrm{NJ}$ tubes (88\% passed at the first attempt within 24 hours) but tube dislodgement, abdominal distension, and ileus limited the rate at which feedings could be increased, particularly in the sicker infants. Others ${ }^{13-15}$ have described similar difficulties. There was no difference in enteral calorie intake at anytime between the two groups.

Infants in the NJ group grew more slowly in weight and occipitofrontal circumference in the neonatal period than infants receiving the same caloric intake by the NG route, and the differences in weight and occipitofrontal circumference paralleled one another suggesting that the differences reflected in the measured growth parameters do indeed represent true differences in growth between the two groups. The increase in growth rate after the newborn period in the NJ group resulting in 'catch up' by EDD +3 months suggests that differences in growth in the neonatal period were due to differences in neonatal management rather than to intrinsic differences in growth potential.
Despite the similarity of the two groups of infants (Table 1) the lack of a formally randomised patient allocation procedure might have resulted in a tendency to inadvertent bias towards sicker infants being included in the NJ group. The presence of a slight (statistically insignificant) preponderance of infants requiring ventilation in the NJ group might be expected to affect growth adversely in the immediate newborn period, but permit catch-up growth later. The NG fed infants of $1.4 \mathrm{~kg}$ or less at birth (Table 3), despite a statistically insignificant slight excess of ventilated infants in the group, still achieved a significantly higher mean IWV.

Infants fed NG from birth reached a higher peak mean IWV than the infants in the NJ group (Fig. 2). Progressive transfer of infants in the NJ group to NG feeding as they reached $1.5 \mathrm{~kg}$ body weight was associated with approximation of the mean IWV curves for the two groups (Fig. 2). The lower weekly mean IWV in the NJ group during the period of $\mathrm{NJ}$ feeding was associated with significantly lower body weight at EDD.

These findings indicate that the differences in mean IWV and attained growth between the two groups are likely to have been owing to differences in feeding in the neonatal period rather than to other factors.

The slower growth rate of $\mathrm{NJ}$ fed infants is likely to reflect greater malabsorption of calories administered enterally by this route. Fat balance measurements were not made in this study but Roy et al., in a study of well infants of weight and gestational age comparable with the infants in this study, found $23 \%$ fat malabsorption in NJ fed infants and $14.9 \%$ in infants fed by the NG route $(P<0.025)$, and considerably greater degrees of enteral malabsorption may be expected in less mature sick infants. ${ }^{15}$

Delivery of milk into the upper jejunum by-passes a significant proportion of the absorptive surface of the upper bowel and digestive processes initiated in the stomach and duodenum. Salivary lipase may be responsible for intragastric lipolysis of a significant proportion of ingested fat in the gastrically-fed preterm infant. ${ }^{16}$ In the present study, gastric aspirates in $\mathrm{NJ}$ fed infants were replaced down the $\mathrm{NJ}$ tube to reduce enzyme and electrolyte losses but salivary lipase is fairly inactive at intestinal $\mathrm{pH}$ and losses of saliva inevitably occurred. Bolus gastric feeding of newborn infants has been shown to induce secretion of enteric hormones, ${ }^{17} 18$ which have local and possibly trophic effects on the bowel. ${ }^{17}$ Continuous infusion of milk into the upper jejunum might influence the acquisition of the enterohormonal responses to feeding and affect functional intestinal maturation. Two studies ${ }^{19} 20$ of preterm infants however, showed no difference in 
blood levels of fat and carbohydrate metabolites, insulin, and pancreatic and enteroglucogen between bolus and continuous gastric feeding ${ }^{19}$ or between continuous gastric and jejunal feeding. ${ }^{20}$ Changes in bacterial flora of the upper bowel induced by transpyloric feeding ${ }^{21}$ may also influence nutrient absorption.

If the values of fat malabsorption of Roy et al. ${ }^{7}$ for NJ- and NG-fed infants are assumed and a value of $4.9 \mathrm{kcal} / \mathrm{g}$ body weight increment for the energy cost of growth in gastrically-fed infants of comparable weight and gestational age, ${ }^{22}$ it can be calculated that an additional $21 \mathrm{kcal} / \mathrm{kg}$ per $24 \mathrm{~h}$ would have had to be administered and be tolerated by the NJ route to support the same weight velocity as infants fed nasogastrically since birth.

The longer-term significance of the difference in growth rates between the two groups is unclear, since catch-up growth had occurred by EDD +3 months, at least as reflected by weights and occipitofrontal circumference measurements. In the first 2 or 3 weeks of life, continuous transpyloric feeding may offer benefits in the smallest infants in reduction of the incidence of apnoeic attacks ${ }^{6}$ and disturbance of respiratory mechanics by feeding. ${ }^{23} 24$ Such possible benefits have not been investigated in controlled prospective trials, and poor nutrient absorption may be a significant problem in such infants. NJ feeding offers considerable benefits in cost over parenteral nutrition, and in nursing time over bolus gastric feeding. ${ }^{25}$

Infants fed by the $\mathrm{NJ}$ route from birth should be transferred to intermittent gastric feeding as soon as possible to promote optimal growth and normal development of gastrointestinal function.

I thank Professor R D G Milner and Dr J A Black for helpful criticism and permission to report cases under their care, the nursing staff who cared for these infants, and Mrs P M Whitfield for help with the diagrams.

\section{References}

1 Uauy R, Loo S W, Gross I, Warshaw J B. Nasojejunal feeding in the small premature infant: a controlled trial (abstract). Pediatr Res 1975; 9: 309.

2 Van Caillie M, Powell G K. Nasoduodenal versus nasogastric feeding in the very low birth weight infant. Pediatrics 1975; 56: 1065-72.

3 Wells D H, Zachman R D. Nasojejunal feedings in low birth weight infants. J Pediatr 1975; 87: $276-9$.

4 Wolfsdorf J, Makarawa S, Fernandes C, Fenner A. Transpyloric feeding in small preterm infants. Arch Dis Child 1975; 50: 723-6.

5 Minoli I, Moro G, Ovadia M F. Nasoduodenal feeding in high risk newborns. Acta Paediatr Scand 1978; 67: 161-8.

- Cheek J A, Jr, Staub G F. Nasojejunal alimentation for premature and full term newborn infants. J Pediatr 1973; 82: 955-62.
7 Roy R N, Pollnitz R P, Hamilton J R, Chance G W. Impaired assimilation of nasojejunal feeds in healthy low birthweight newborn infants. J Pediatr 1977; 90: 431-4.

8 Drew J H, Johnston R, Finocchiaro C, Taylor P S, Goldberg H J. A comparison of nasojejunal with nasogastric feedings in low birthweight infants. Aust Paediatr $J$ $1979 ; 15$ : 98-100.

- Hey E N, O'Connell B. Oxygen consumption and heat balance in the cot-nursed baby. Arch Dis Child 1970; 45: 335-43.

10 Benda G I. Modes of feeding low birth weight infants. Semin Perinatol 1979; 3: 407-16.

11 Usher R, McLean F. Intrauterine growth in liveborn caucasian infants at sea level: standards obtained from measurements in 7 dimensions of infants born between 25 and 44 weeks of gestation. J Pediatr 1969; 74: 901-10.

12 Tanner J M, Whitehouse R H, Takaishi M. Standards from birth to maturity for height, weight, height velocity, and weight velocity of British children, 1965. Arch Dis Child 1966; 41 : 454-71, 613-35.

13 Hyde J. Transpyloric feeding in the new born. Br J Hosp Med 1978; 19: 618-22.

14 Beddis I, McKenzie S. Transpyloric feeding in the very low birth weight (1500 $\mathrm{g}$ and below) infant. Arch Dis Child 1979; 54: 213-7.

15 De Carvalho M, Davis J A, Hudson G J, Coward W A. Letter: Gastric and jejunal feeding in high risk neonates. Arch Dis Child 1980; 55: 575.

16 Hamosh M, Sivasubramanian K N, Salzman-Mann C, Hamosh P. Fat digestion in the stomach of premature infants. J Pediatr 1978; 93: 674-9.

17 Lucas A, Adrian T E, Christofides N, Bloom S R, Aynsley-Green A. Plasma motilin, gastrin, and enteroglucagon and feeding in the human newborn. Arch Dis Child 1980; 55: 673-7.

18 Lucas A, Bloom S R, Aynsley-Green A. Development of gut hormone responses to feeding in neonates. Arch Dis Child 1980; 55: 678-82.

19 Lucas A, Bloom S R, Aynsley-Green A. Metabolic and endocrine events at the time of the first feed of human milk in preterm and term infants. Arch Dis Child 1978; 53: 731-6.

20 Milner R D G, Minoli I, Moro G, Rubecz I, Whitfield M F, Assan R. Growth and metabolic and hormonal profiles during transpyloric and nasogastric feeding in preterm infants. Acta Paediatr Scand 1981; 70: 9-13.

21 Challacombe D N, Richardson J M, Anderson C M. Bacterial microflora of the upper gastro-intestinal tract in infants without diarrhoea. Arch Dis Child 1974; 49: $264-9$.

22 Sinclair J C. Caloric equivalent of weight gain in the low birth weight infant. In: Winters $R$ W, Hasselmeyer E G, eds. Intravenous nutrition in the high risk neonate. New York: Wiley, 1975: 91-6.

${ }^{23}$ Yu VY H. Cardiorespiratory response to feeding in newborn infants. Arch Dis Child 1976; 51: 305-9.

24 Yu VY H, Rolfe P. Effect of feeding on ventilation and respiratory mechanics in newborn infants. Arch Dis Child 1976; 51: 310-3.

25 Whitfield M F. Letter: Transpyloric feeding in infants undergoing intensive care. Arch Dis Child 1981; 56: 571.

Correspondence to Dr M F Whitfield, Division of Neonatology, Department of Paediatrics, University of British Columbia, 4480 Oak Street, Vancouver BC, V6H 3V4, Canada.

Received 5 May 1982 